\title{
Nursing Bachelor's Education Program in Iran and UCLA: A Comparative Study
}

\author{
Adib Hajbaghery. $\mathrm{M}^{1}$ \\ Mazhariazad. F2 \\ 1- ( ${ }^{*}$ Corresponding Author) \\ Ph.D. in Nursing, Professor, \\ Trauma Nursing Research \\ Center, Medical-Surgical \\ Department Kashan University \\ of Medical Sciences, Kashan, \\ Iran. \\ Email: adib1344@yahoo.com \\ 2- MSc in Nursing, Instructor, \\ Medical-Surgical Department \\ Faculty of Nursing, Azad \\ university of Bandar Abbas \\ Branch, Bandar Abbas, Iran.
}

\begin{abstract}
Introduction: Considering the world's most successful educational systems is an indication for the institutionalization of an effective system and comparing different educational systems will promote the content and quality of the curriculum.
\end{abstract}

Objective: The aim of this study was to conduct a comparative study of nursing Bachelor's Education Program in Iran and University of California, Los Angeles (UCLA).

Material and methods: This descriptive-comparative study was performed in 2018, data were collected by googling the key words of nursing, nursing education, curriculum, California UCLA and Iran, and a review of the history and details of the nursing Bachelor's education program in Iran and UCLA and analyzed using Bereday's four-stage model including description, interpretation, juxtaposition and comparison.

Results: The goals, missions and structures of both programs are similar. Considering the characteristics and cultural diversity of patients, the patient-centered approach, caring for the high quality and safe care are the goals of the UCLA Nursing Faculty to the, which is less common in Iran. There are some differences in the pre-requisite courses.. In UCLA Nursing School, clinical education is done in the simulator lab equipped with the most updated educational technology, but in Iran, it is conducted in a clinical setting, using modern educational approaches is less common in Iran. Graduates at UCLA are not allowed to work until getting RN (Registered Nurse) license, but they start working in Iran after graduation.

Discussion and Conclusion: Considering that the program of nursing undergraduate studies in Iran was revised in 2014, performing descriptive studies on acquired competencies and program content can help to improve the program by problem solving.

Keywords: Bachelor of Nursing, Comparative Study, Iran, UCLA. 


\title{
UCLA مقايسه تطبيقى نظام آموزشى كارشناسى يرستارى در ايران با دانشعاه
}

\author{
"محسن اديب حاج باقرى'، فرشته مظهرى آزادr"
}

جكيده

مقدمه: توجه به نظامهاى آموزشى موفق در جهان، مبين نهادينه شدن يك نظام كار آمد و اثربخش است و مقايسه نظامهاى .

$$
\text { مختلف آموزشى باعث ارتقاى محتوى و كيفيت برنامه آموزشى مى ترى دهد. }
$$

هدiversity of California, هدف: هدف اين مطالعه مقايسه برنامه آموزشى مقطع كارشناسى يرستارى در ايران با دانشعاه Los Angeles) UCLA مواد و روشها: مطالعه مقايسهاى حاضر با استفاده از رويكرد توصيفى - تطبيقى در سال Y Y I انجام شد و اطلاعات مورد نياز در مورد برنامه آموزشى كارشناسى يرستارى با جستجوى اينترنتى با كليد وازههاى ڤيرستارى، يرستار، آموزش يرستارى، كوريكولوم، برنامه درسى، UCLA و ايران جمع آورى گرديد و با استفاده از الگوى بردى (Bereday) و در :ههار مرحله توصيف، تفسير، هم جوارى و مقايسه مورد تجزيه و تحليل قرار گرفت. يافتهها: نشان داد كه رسالت و اهداف و ساختار كلى هر دو برنامه تشابهات زيادى وجود دارد، با اين تفاوت كه توجه به ويزگى ها و تنوع فرهنگى مراجعين، بيمار مدارى، توجه به ارائه مراقبت باكيفيت و ايمن از اهداف دانشكده يرستارى UCLA آموزش بالينى در دانشكده پرستارى UCLA آزمايشگاه شبيه ساز مجهز به يِيشرفتهترين تكنولوزى آموزشى است، اما در ايران در محيط بالينى اجرا مىشود و استفاده از رويكردهاى نوين آموزش مىباشد كه در ايران كمتر به جشم مى خورد. دانش آموختعان در UCLA بدون دريافت مجوز RN (Registered Nurse) اجازه اشتغال به كار ندارند، اما در ايران بعد از فارغ التحصيلى شروع به كار مى كنند. بحث و نتيجه گيرى: با توجه به اينكه برنامه رشته كارشناسى يرستارى در ايران، در سال سوسا مورد بازنخرى قرار گرفته

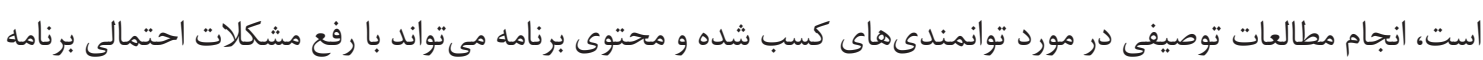

$$
\text { به ارتقاى هر جه بيشتر آن كمك نمايد. }
$$

\begin{tabular}{|c|c|c|}
\hline $1 \mu q V / 1 Y / 9$ & 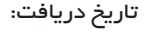 & 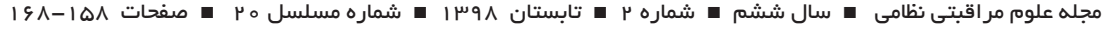 \\
\hline$|\mu q \Lambda / \mu / \mu|$ & تاريخ يذيرش: & \\
\hline І & 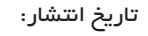 & \\
\hline
\end{tabular}

كلمات كليدى: ايران، كارشناسى يرستارى، مطالعه تطبيقى.

كند (Г). برنامه درسى از مؤلفههاى اصلى يك نظام تربيت رسمى مقدمه

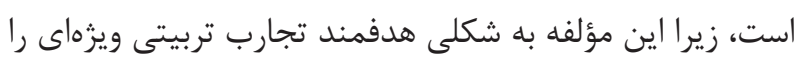
دانشكاهها و مؤسسات آموزش عالى به عنوان مجرى نظامهاى

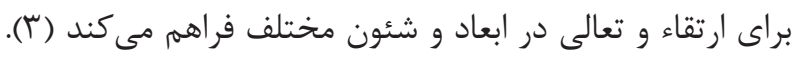

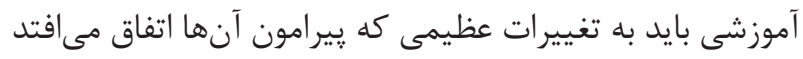

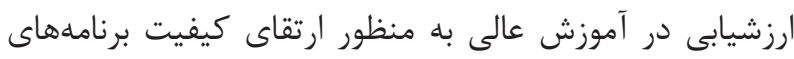

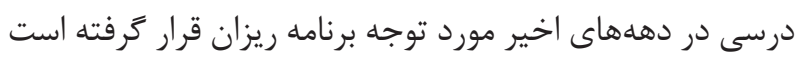

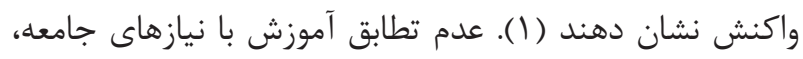

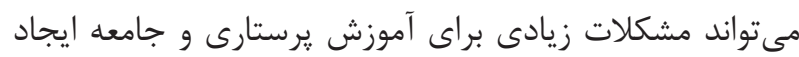


ضرورى دانسته و لزوم تغييرات در برنامه درسى را پيشنهاد كرده است (I) (I).

توجه به نظامهاى آموزشى موفق در جهان، مبين نهادينه شدن

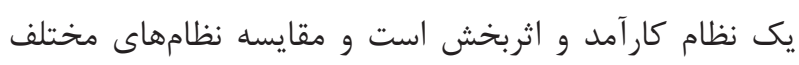

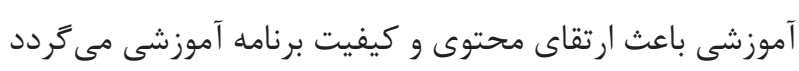

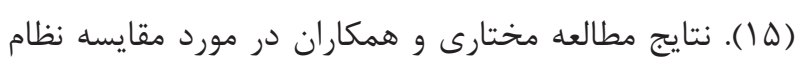

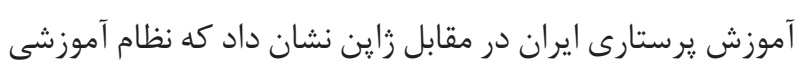

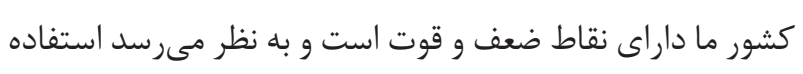

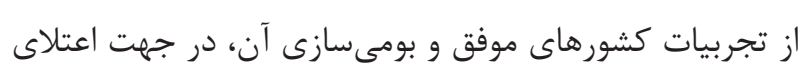
سيستم آموزش يرستارى ايران كمك خواهد نمود (ع) (1). با توجه

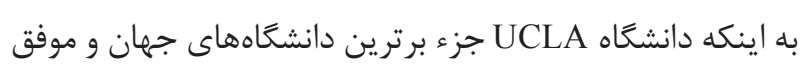
در امر آموزش يرستارى مىباشد، اين مطالعه با هدف مقايسه

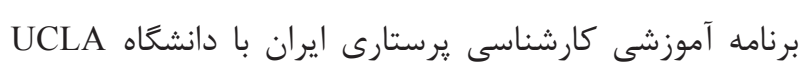
انجام شده است.

\section{مواد و روشها - - ماد}

مطالعه مقايسهاى حاضر با استفاده از رويكرد تطبيقى در سال

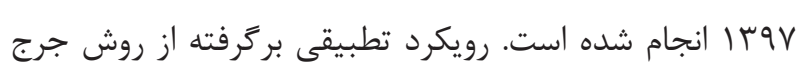
اف بردى است كه در تهار مرحله توصيفى (Description)، تفسير (Interpretation)، همجوارى (Juxtaposition) و مقايسه

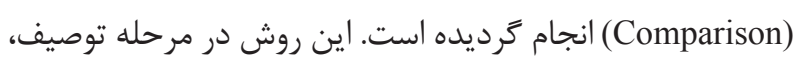

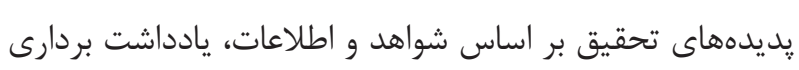

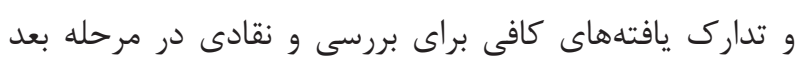

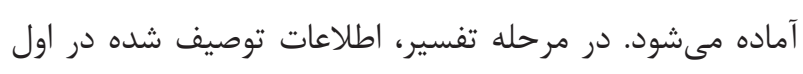

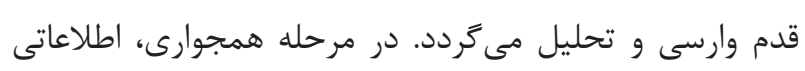

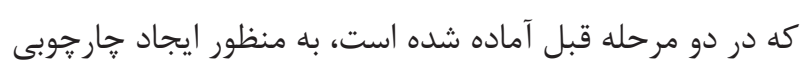
براى مقايسه شباهتها و تفاوتها طبقه بندى و در كنار هم قرار مى گيرد. در مرحله مقايسه، مسئله تحقيق با توجه به جزئيات

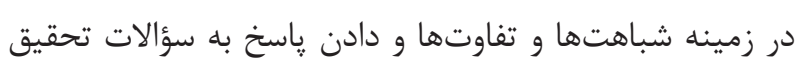
بررسى و مقايسه مى

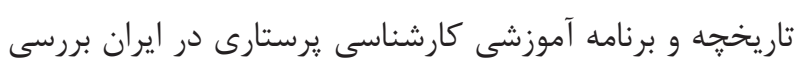

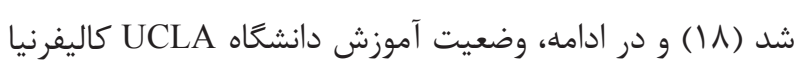
مورد مطالعه (19) و سيس وجه اشتراك و افتراق اين برنامهها

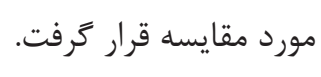

(1). توجه به شاخصهاى كيفى و ارتقاى كيفيت آموزش در

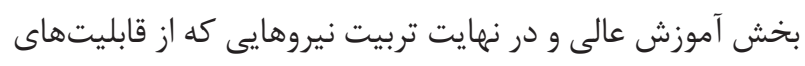
اخلاقى، علمى و عملى كافى برخوردار باشند، از اهداف اين مقوله

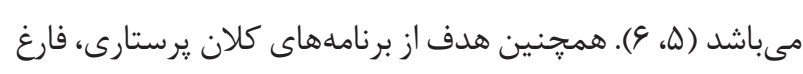

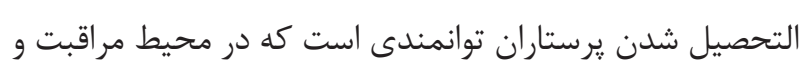

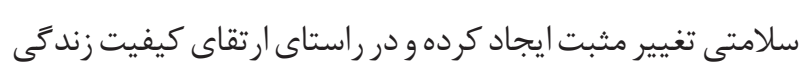

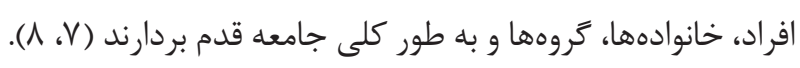

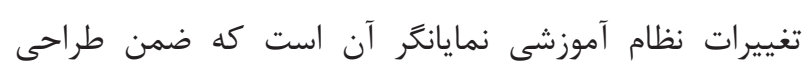

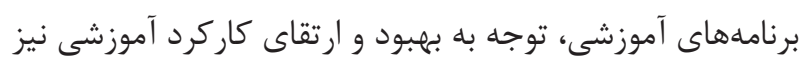

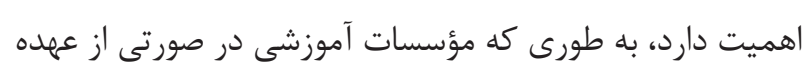

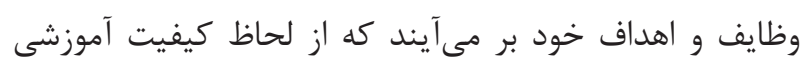

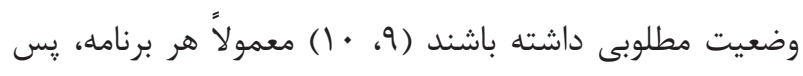

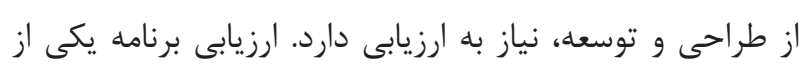

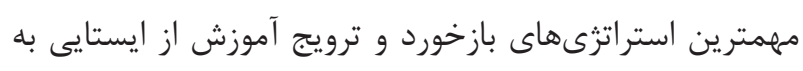
يويايى است (1)

يكى از اهداف دانشعاههاى علوم يزشكى، رسيدن الان به موقعيت

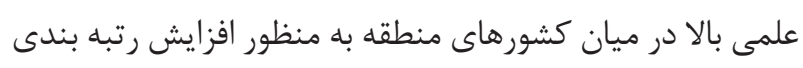
جهانى است. بدون ترديد، رسيدن به موقعيتى عالى در جهان

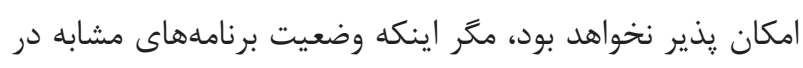

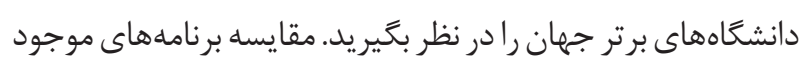

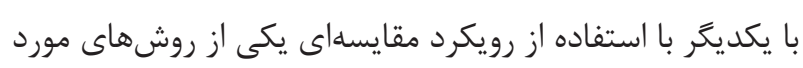

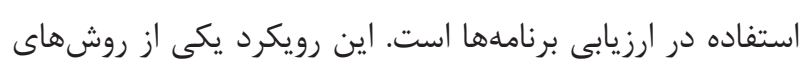
تحقيقاتى در علوم اجتماعى است كه مى تواند براى مقايسه كشور ها

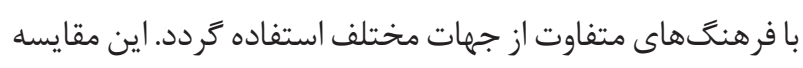

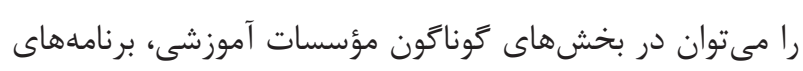

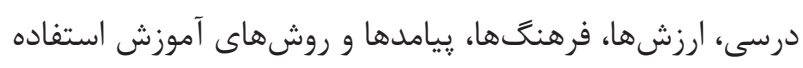

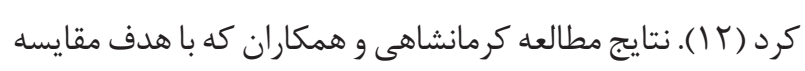
برنامه آموزش كارشناسى ارشد كودكان در ايران و كانان مطادا انجام

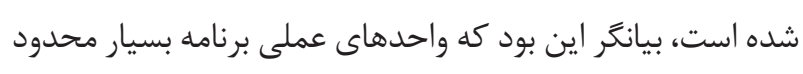

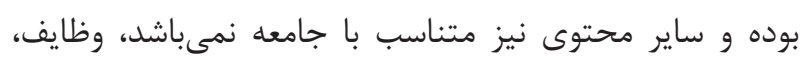

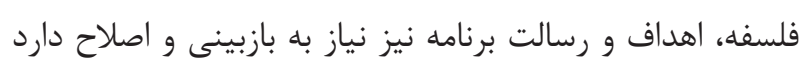
(ب (1). نيك فريد و همكاران در مطالعه خود تغييرات زير بنايى در

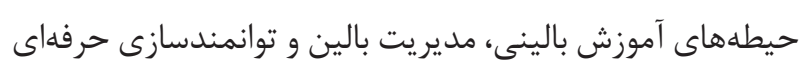
را براى تضمين موفقيت رشته يرستارى و مراقبتهاى ويزره نوزادان 
مشخصات و ساختار و دوره (جدول ه)، محتواى دوره (جدول ؟) و راهبردهاى آموزشى (جدول V)، ارائه شده است.

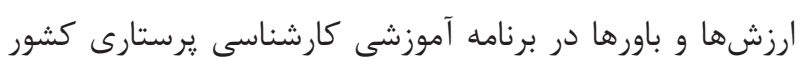

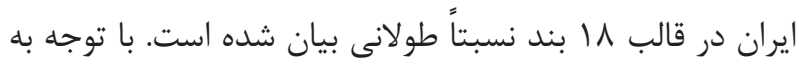

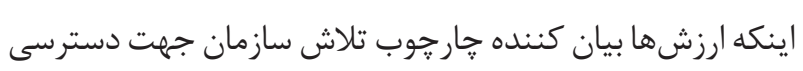

يافته ها

نتايج به دست آمده از مقايسه برنامه درسى كارشناسى يرستارى

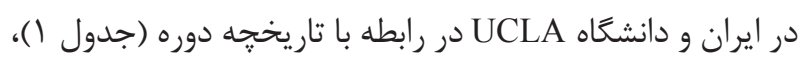

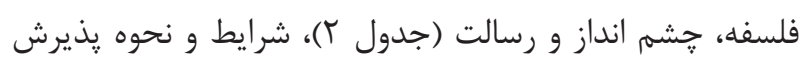

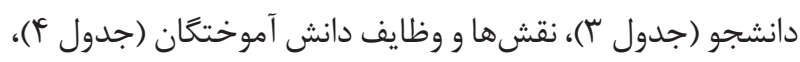

جدول ا- تاريخجه دوره

دانشكاه

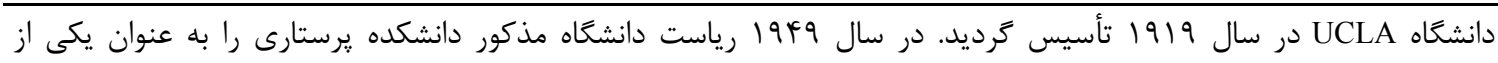

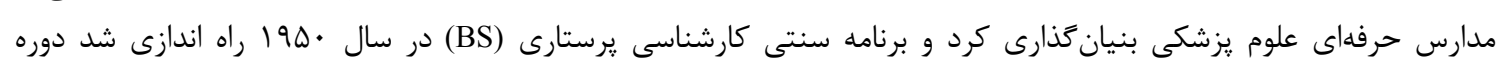

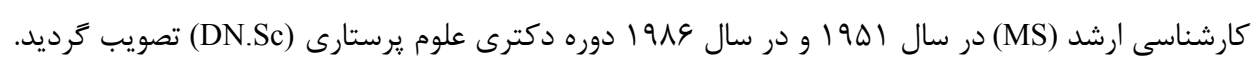

UCLA

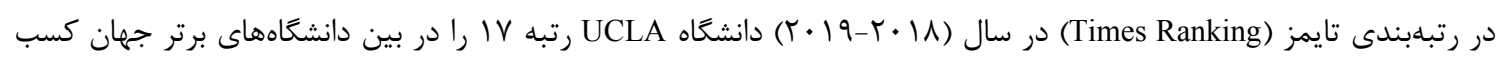

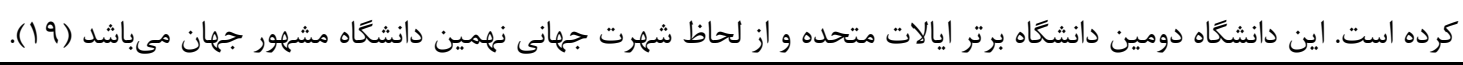

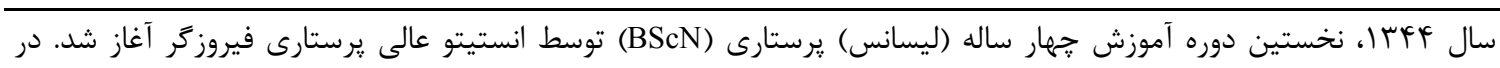

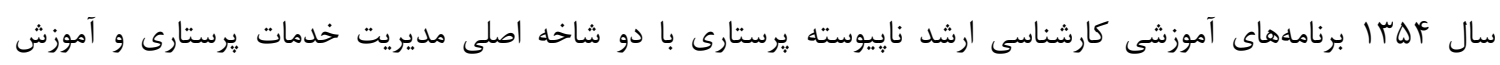

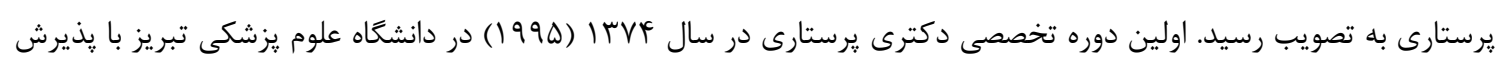
r ب دانشجو آغاز شد (1) (1).

جدول r- مقايسه فلسفه، جشم انداز و رسالت در دانشعاههاى مورد مطالعه فلسفه، جششم انداز و رسالت دانشعاه

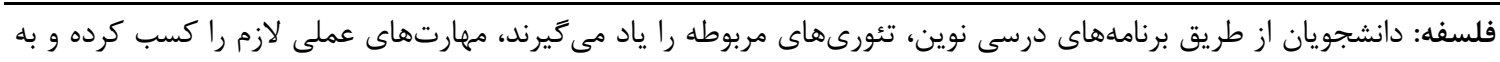

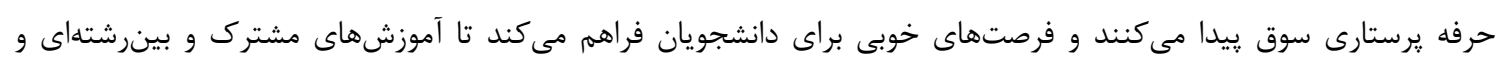

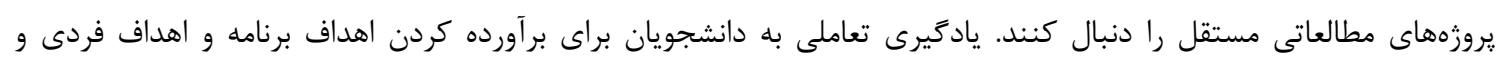

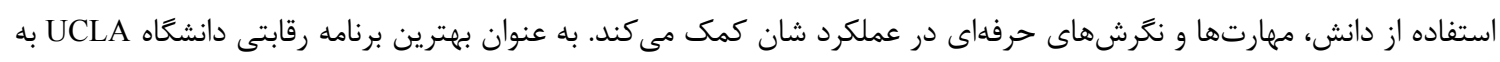

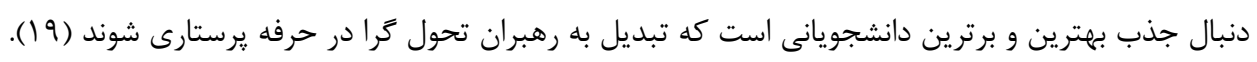
UCLA

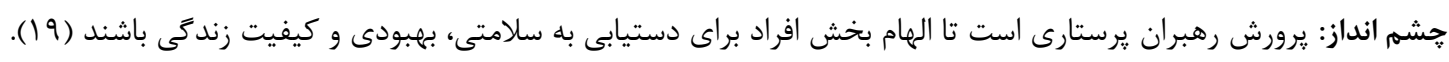

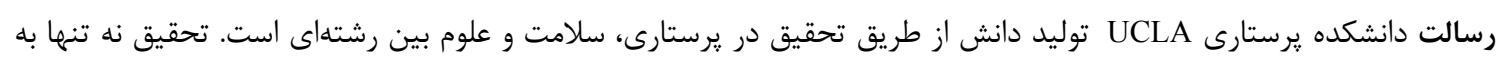

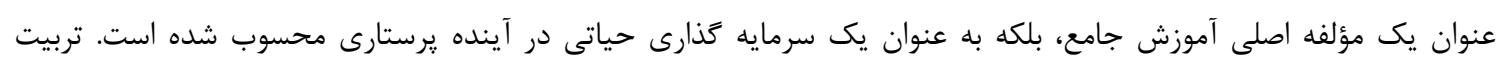

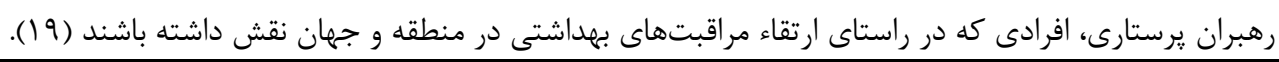

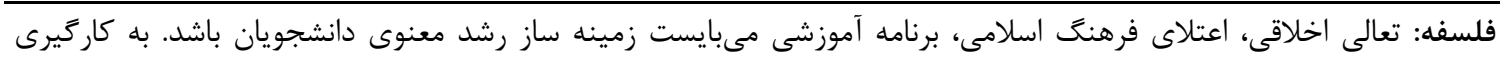

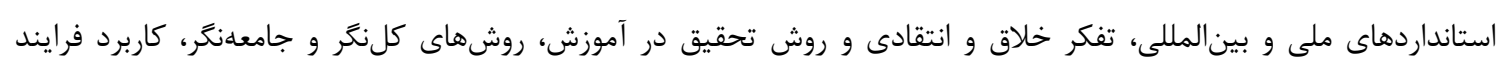

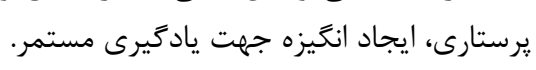

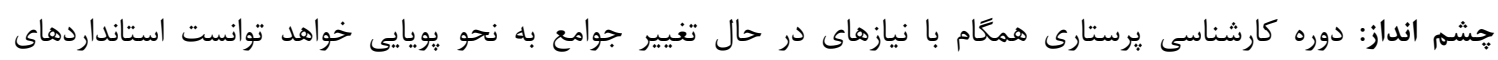

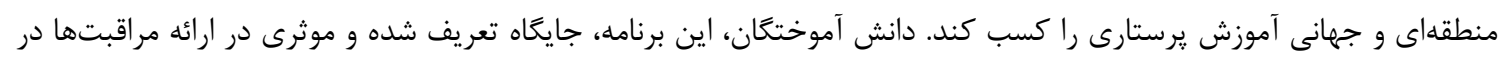

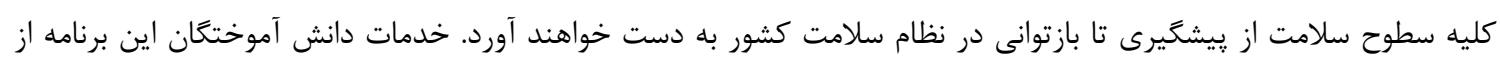

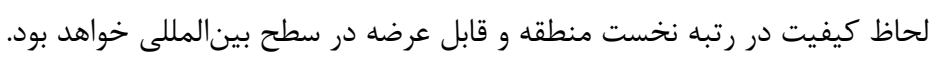

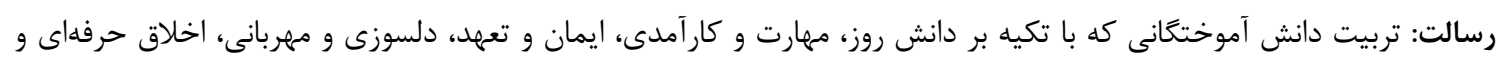

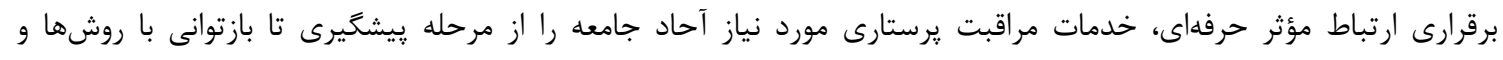

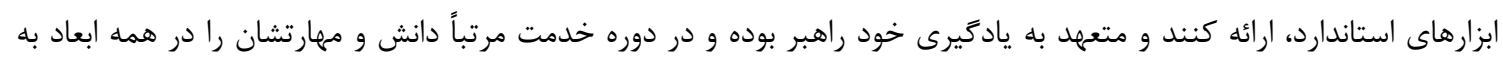
روزرسانى كنند (•r). 
مدرك Bachelor of Science) BS است. دانشجويان پس از

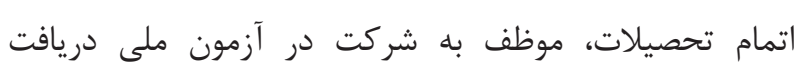

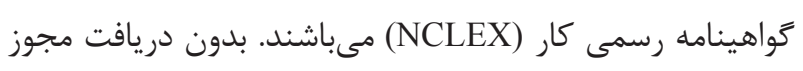

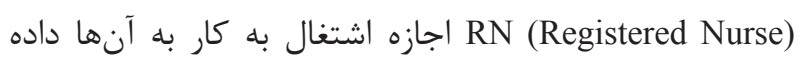
نمىشود. اين مدرك براى ورود به مقطع كارشناسى ارشد كه

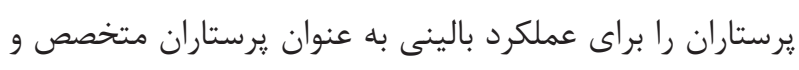

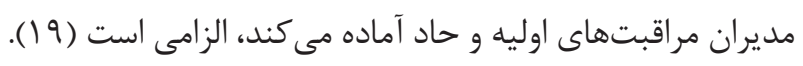

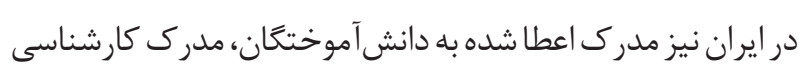

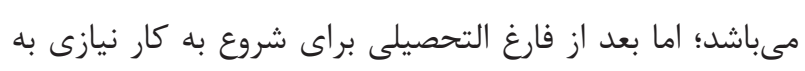

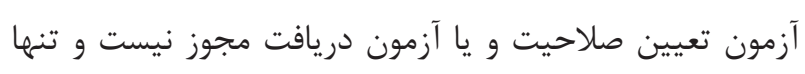

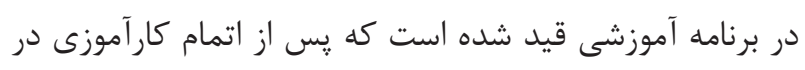

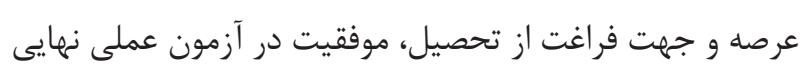

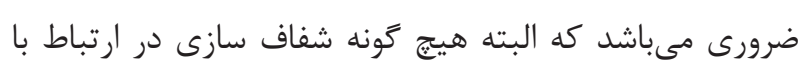

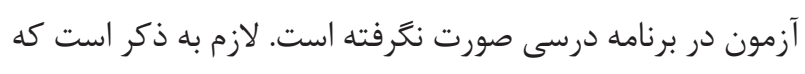

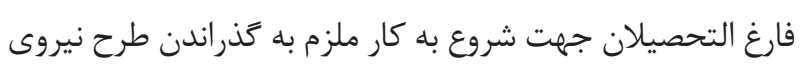

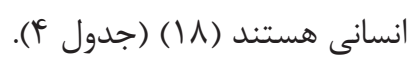

به اهداف خود مىباشند و هرگز قابل تخطى نخواهند بود، بيان

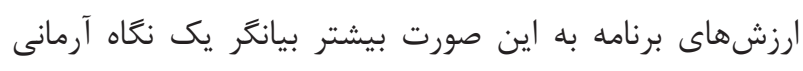

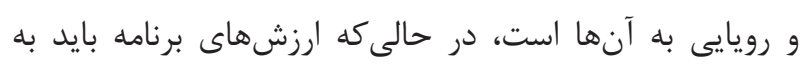

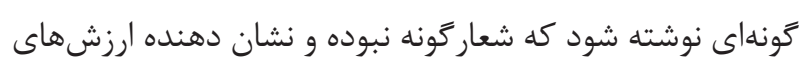

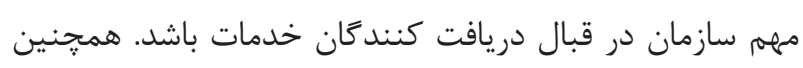
با توجه به اهميتى كه دارند در قالب برنامه هاى عملياتى سازمان قابل اجرا باشند (جدول r) باله

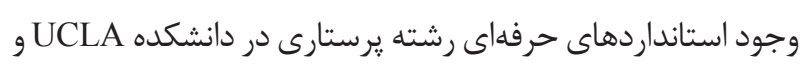

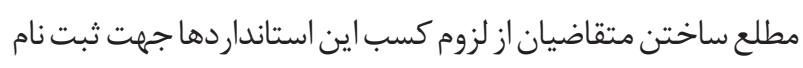

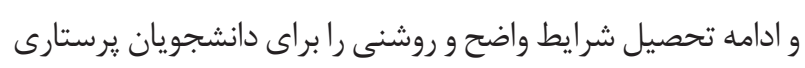
و سيستم آموزش فراهم مى سازد و دانشجويان در تمام دور ان تحصيل

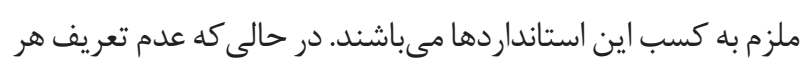

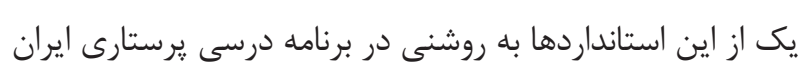

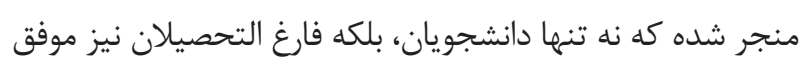
به كسب يايينترين حد اين مهارتها نيز نشده باشند (جدول سانه). در دانشكده يرستارى UCLA، مدرك اعطايى به دانش آموختگان،

جدول r - شرايط و نحوه يذيرش دانشجو شرايط و نحوه يذيرش دانشجو

دانشآموزان بعد از اتمام دوره دبيرستان مىتوانند به عنوان دانشجوى سال اول وارد برنامه كارشناسى \& ساله يرستارى شوند.

$$
\text { جهت ورود به مدرسه يرستارى UCLA مدارى زير مورد نياز است: }
$$

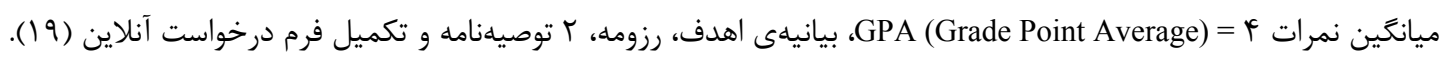

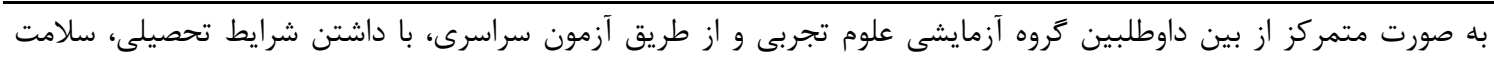

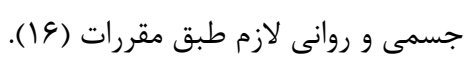

جدول F - نقشها و وظايف حرفهاى دانش آموختعان

\section{نقشها و وظايف حرفهاى دانش آموختكان} دانشعاه

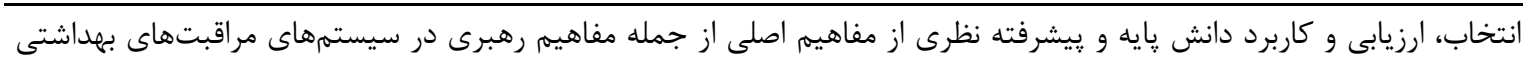

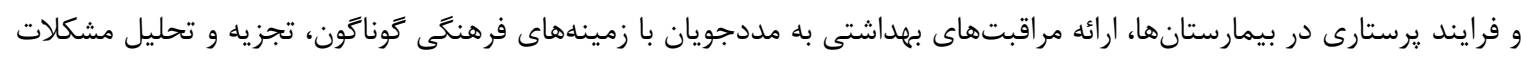

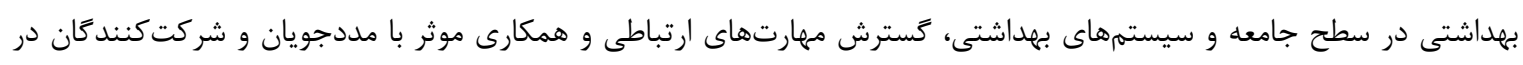

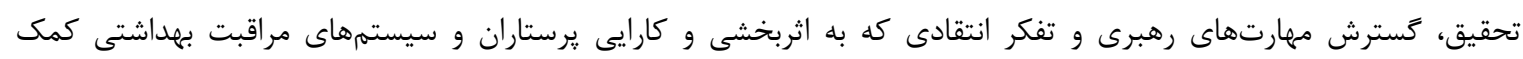

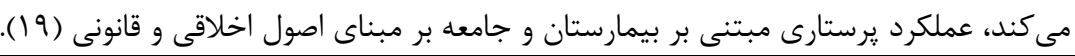

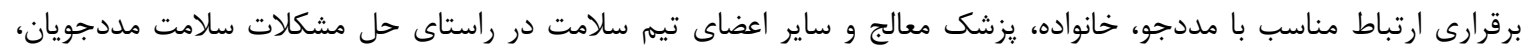

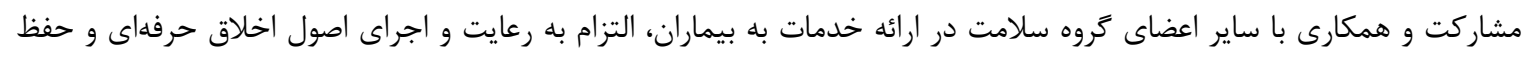

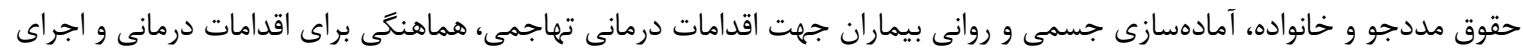
ايران

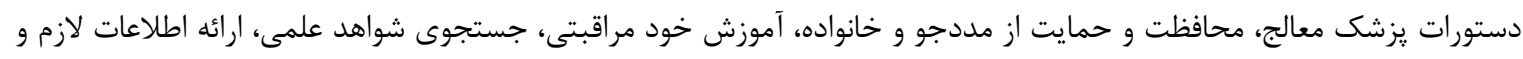

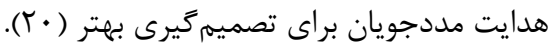


جدول ه - مشخصات و ساختار و دوره كارشناسى يرستارى

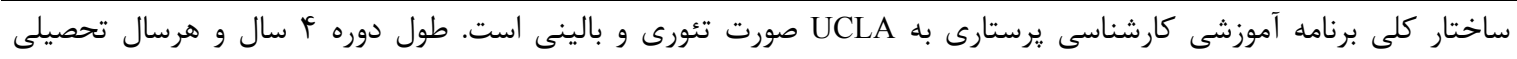

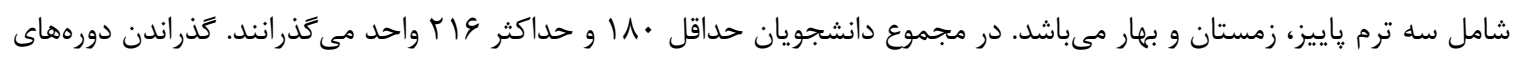
UCLA

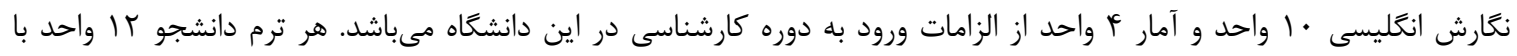

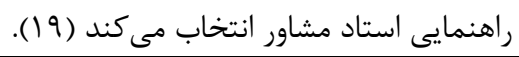

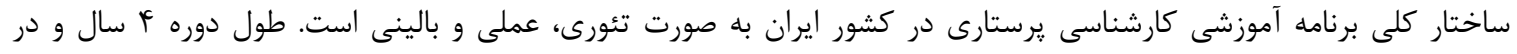

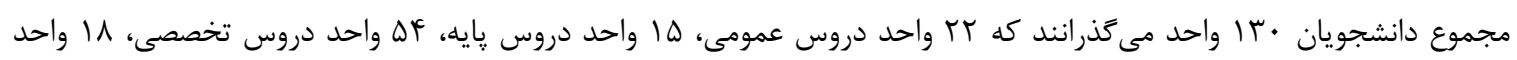

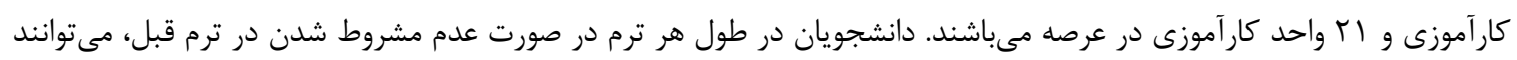

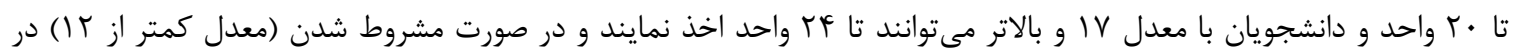

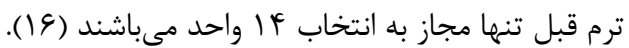

به بالين نياز به كسب مجوزهاى خاص و كَراندن دورههايى از

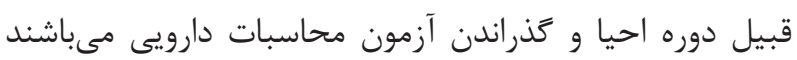

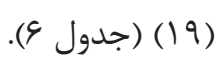

انتخاب روش تدر يس به نوع و موضوع درس بستخى دارد. استفاده

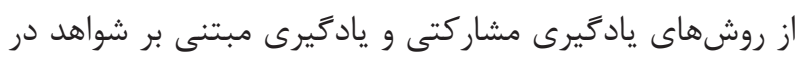

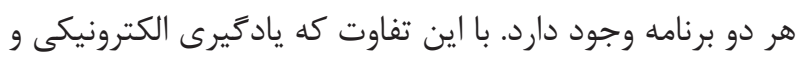

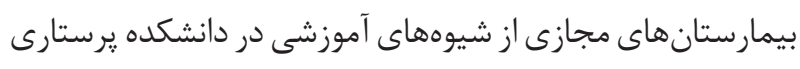
UCLA

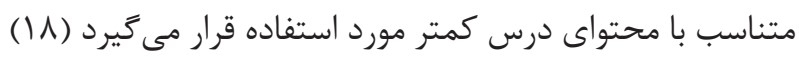

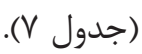

\section{بحث و نتيجه}

مطالعه حاضر با هدف مقايسه برنامه آموزشى مقطع كارشناسى ديرى

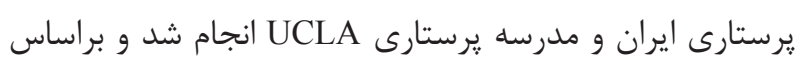

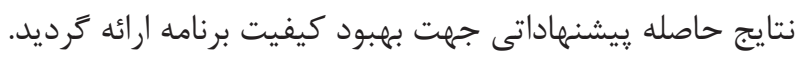
برخلاف دانشخاه UCLA كه در هيج يك از مقاطع تحصيلى آزمون

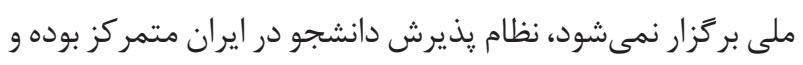

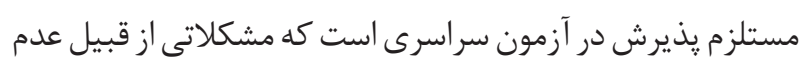

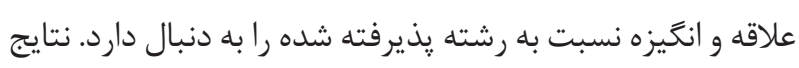

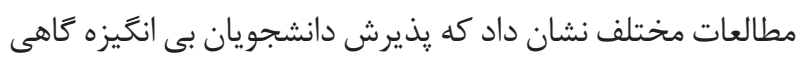

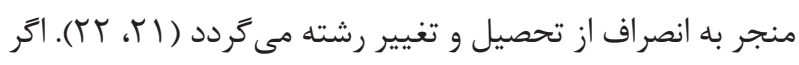
جه داشتن سلامت جسمى و روانى به عنوان شرط پِذيرش در ايران

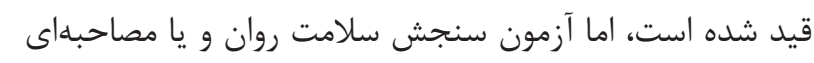

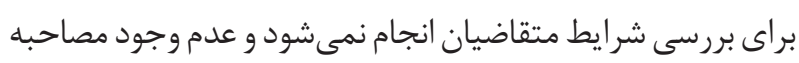

مقايسه ساختار برنامه كارشناسى يرستارى دانشگاه UCLA با

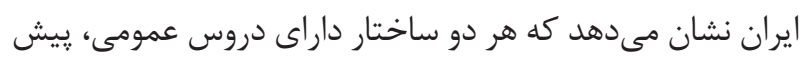

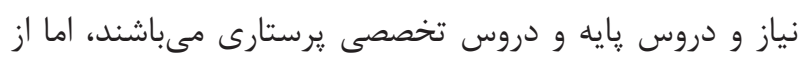

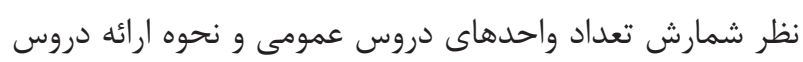
تخصصى يرستارى و دروس ييش نياز تفاوتهايى وجود دارد. ارائه

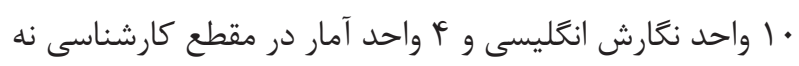
تنها براى دانشجويان رشته يرستارى، بلكه براى كليه دانشجويان

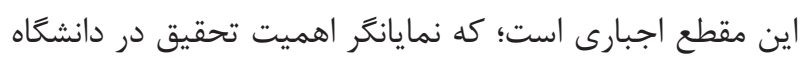
UCLA است. دركوريكولوم جديد كارشناسى يرستارى ايران كذراندن

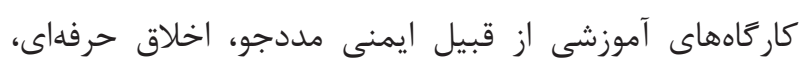

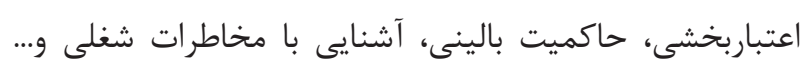
ضرورى مىباشد (1) (1) (جدول ه).

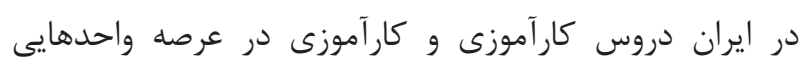

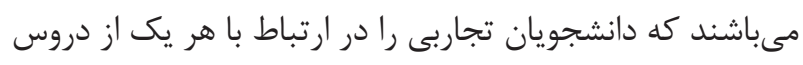
تئورى تخصصى يرستارى در محيطهاى بالينى كسب خواهند

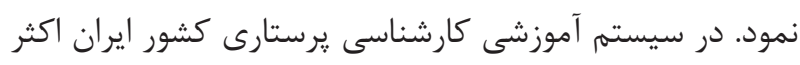
واحدهاى كارآموزى در محيطهاى بالينى (بيمارستانها و مراكز

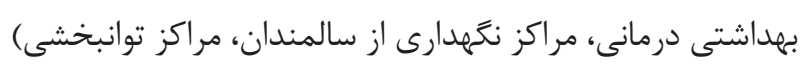

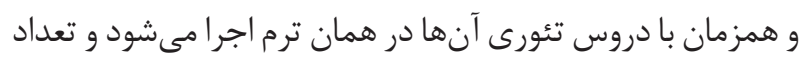

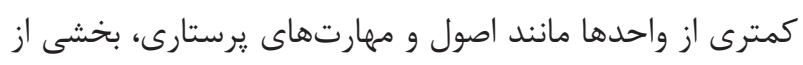
واحد فوريتهاو اتاق عمل در مركز مهارتهاى بالينى (Skill lab)

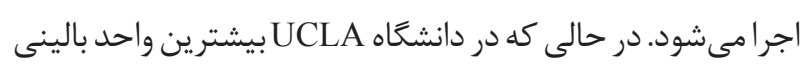

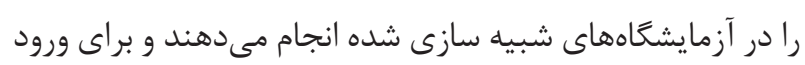


جدول \&- محتواى دوره

\section{محتواى برنامه درسى}

اين دوره داراى دروس عمومى، پايه و تخصصى مى باشد كه در ذيل آمده است.

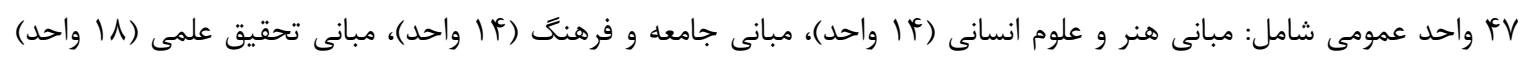
مىباشد. دورههاى ذكر شده به عنوان آمادكى براى ورود به دور مهاى اصلى برستارى است.

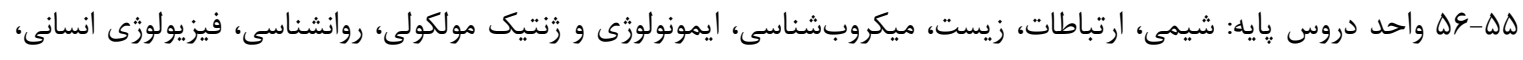

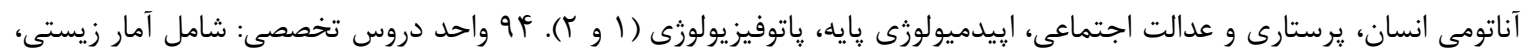

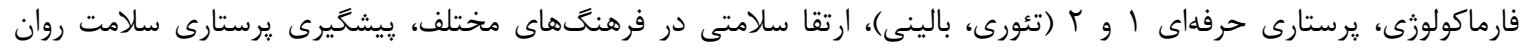

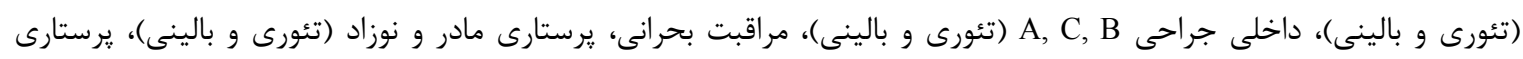

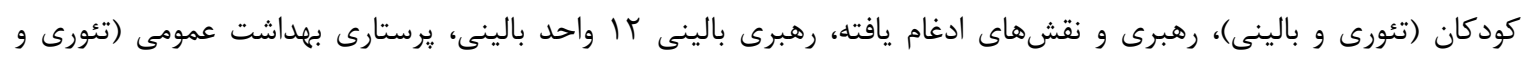

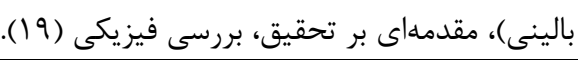

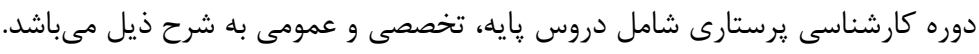

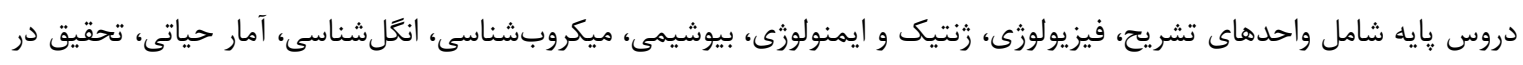

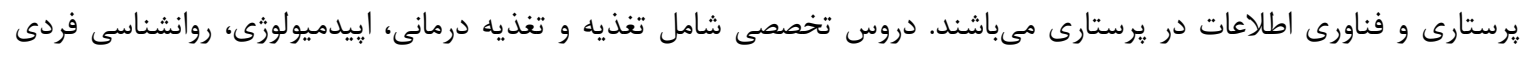

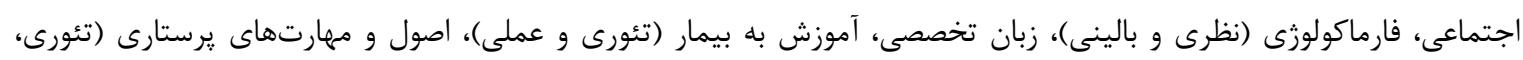

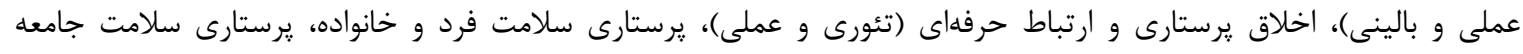

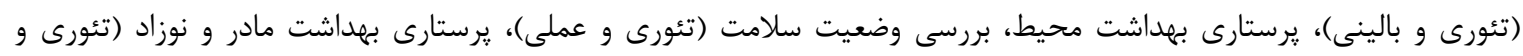

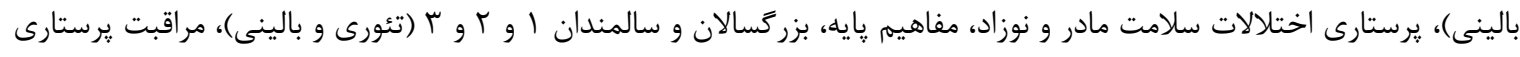

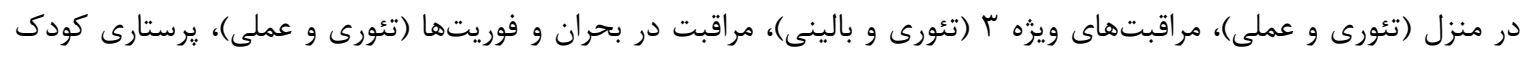

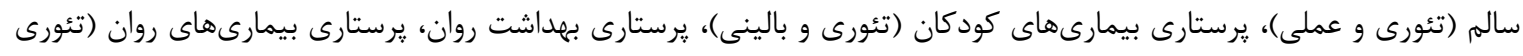

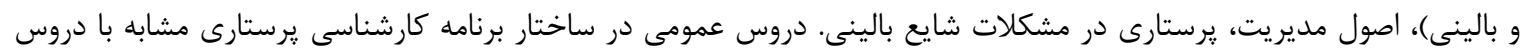
عمومى ساير رشتهاى كارشناسى در كشور ايران مى اصباشد (1) (1).

\begin{tabular}{|c|c|}
\hline روشهاى ياددهى و يادكيرى & 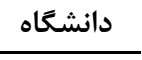 \\
\hline 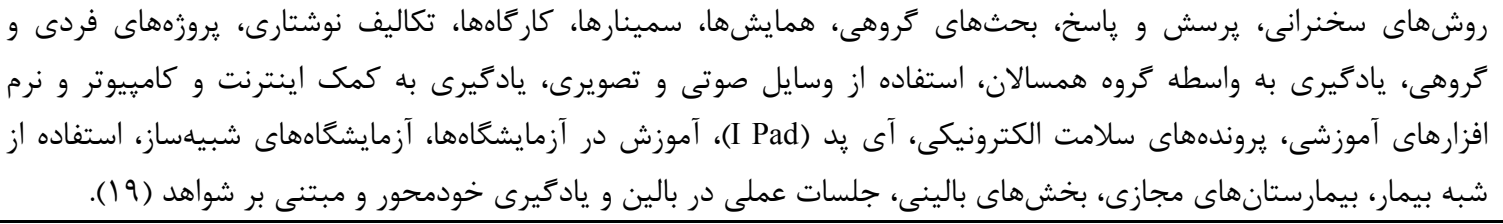 & UCLA \\
\hline 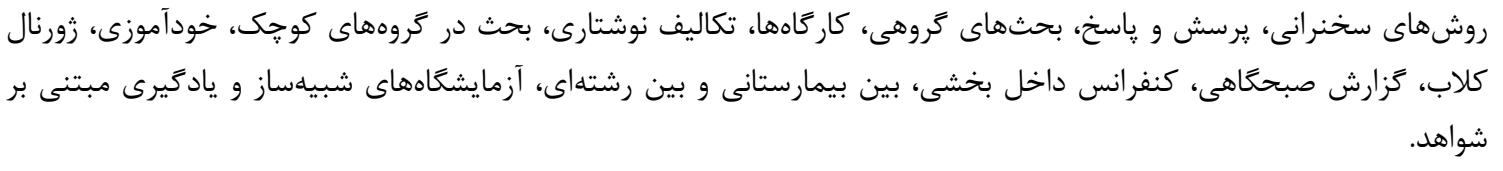 & ير'U \\
\hline روشها و فنون بر حسب نياز و اهداف فراگير (1)). & \\
\hline
\end{tabular}

همكاران استفاده از روشهاى غير متمركز و معيارهاى جند

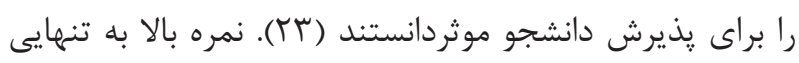

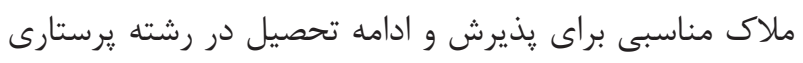

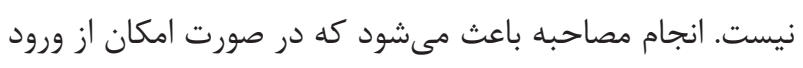
داوطلبان بى علاقه يا داوطلبانى كه فقط تلاش داعت دارند تا از قافله
و عدم بررسى ويزگى هاى شخصيتى، اخلاقى، علايق، نخرشها،

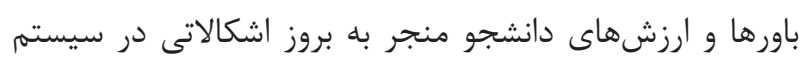

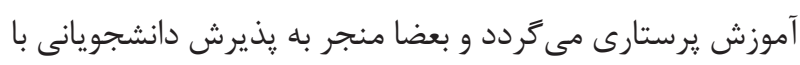

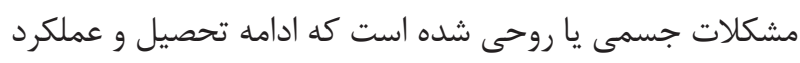

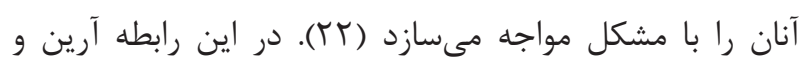


شروع كار به عنوان يرستار، برَزار مى گردد، اما در ايران، جنين

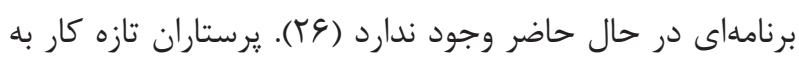

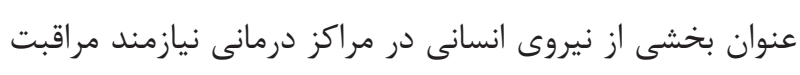

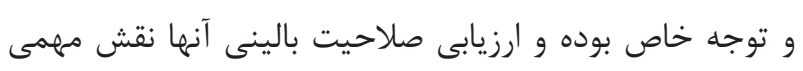

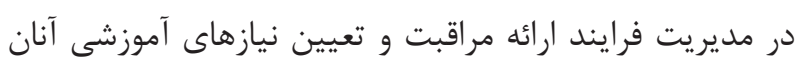

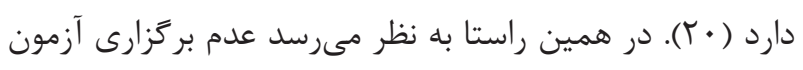
RN (Registered Nurse) بسيارى از كشورها بركزار مىشود، در سيستم يرستارى ايران هم

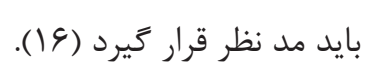
محتواى برنامه درسى طورى انتخاب، سازماندهى و تدوين مى كر مدرد

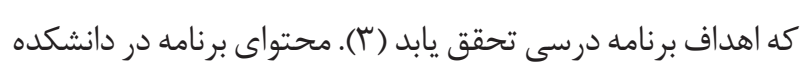

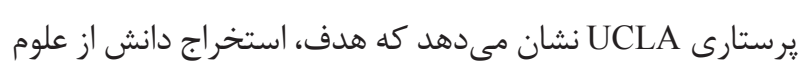

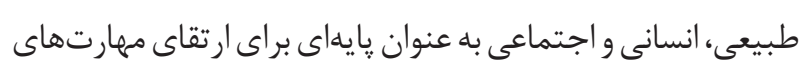

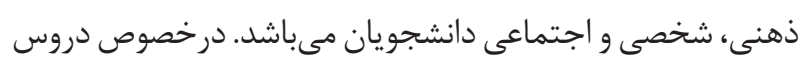

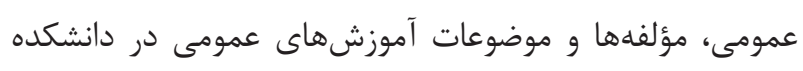

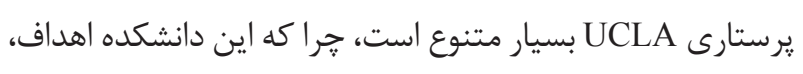

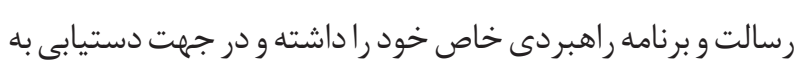

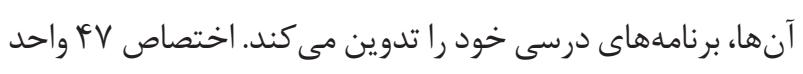
درسى به دروس غير يرستارى بيانكر اين موضوع مىباشد (9 (1).

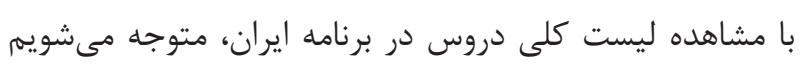

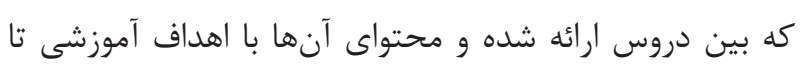

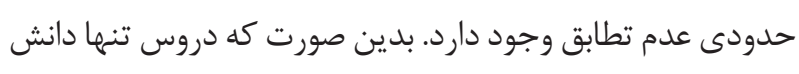
و مهارتهاى خاص علمى را انتقال مى دهند، اما نمى توان توانايى

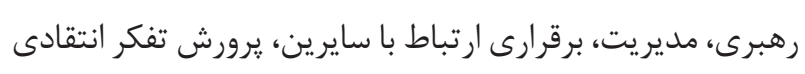

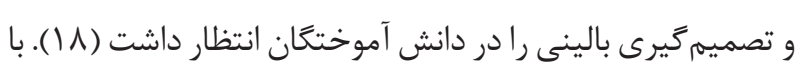

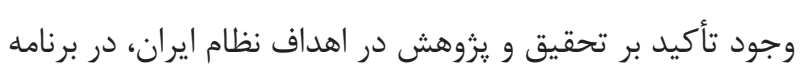

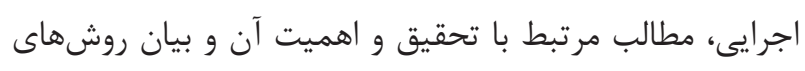
آمارى مرتبط در قالب اين تعداد واحد، نمىتواند تأمين كننده

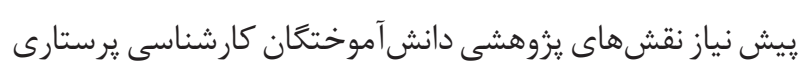

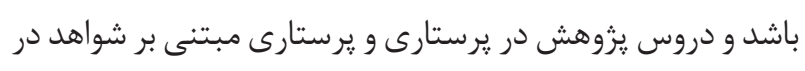

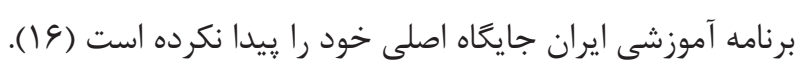

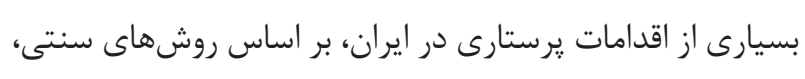

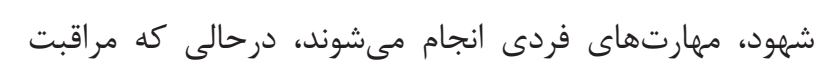

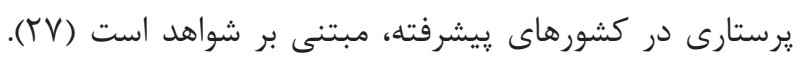

قبول شدَان كنكور سراسرى عقب نمانند، جلو گيرى شود (T).

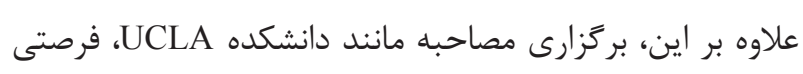

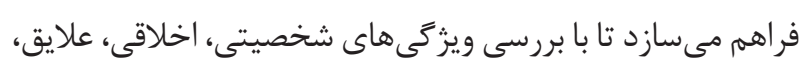

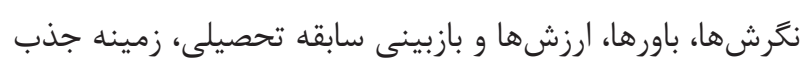

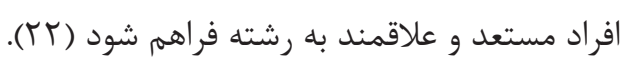

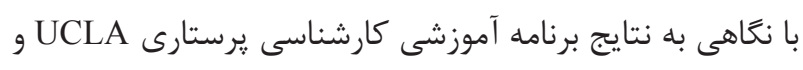

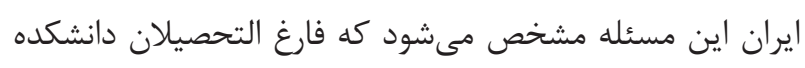

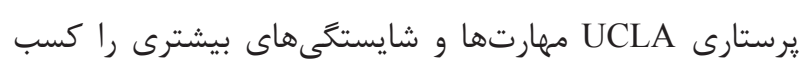

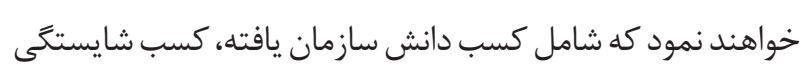
و مهارت خاص، توانايى حل مشكل، تفكرانتقادى، قضاوت بالينى،

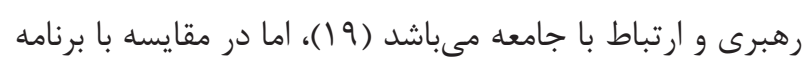
آموزشى كارشناسى يرستارى ايران به نظر مى رسد ارتباط انتظار داشتن

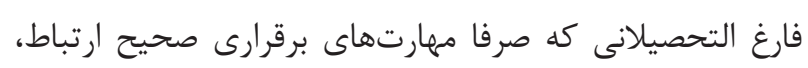

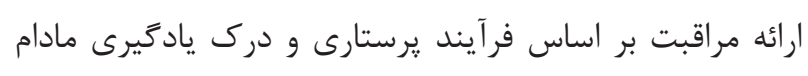

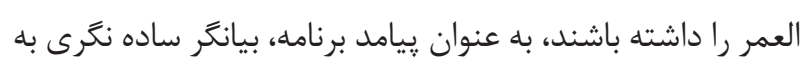
جايغاه ويزه برستاران در سيستم خدمات بهداشتى درمانى كشور

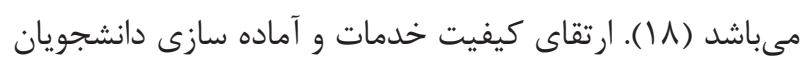
يرستارى براى به عهده كرفتن مسئوليتهاى شغلى و انجام وظايف

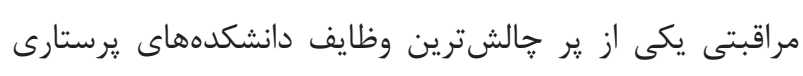

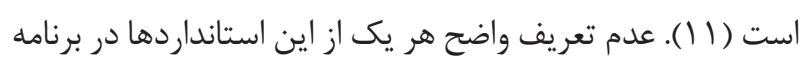

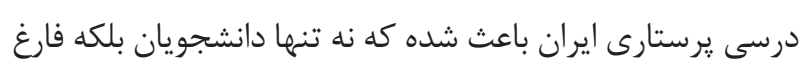
التحصيلان نيز شايستخى هاى لازم جهت كسب اين استانداردها

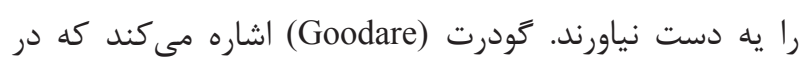
سطح بين المللى، فارغ التحصيلان جديد يرستارى در اولين سال

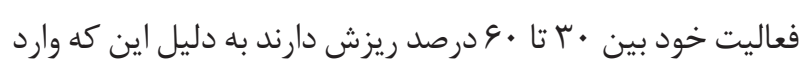

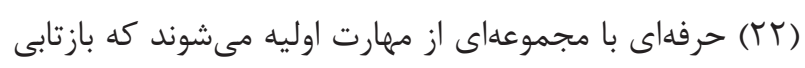

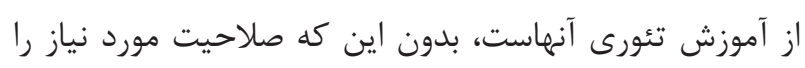

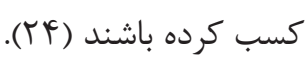
تضمين كيفيت مراقبتها و كسب اطمينان از صلاحيت بالينى يرستاران شاغل در بيمارستان هاو ساير مؤسسات مر اقبتى، دغدينه

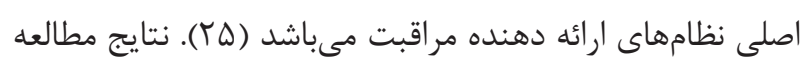

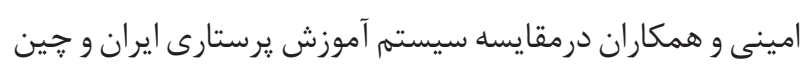

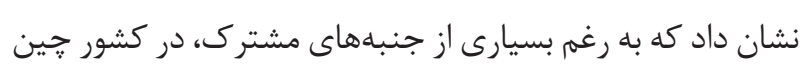

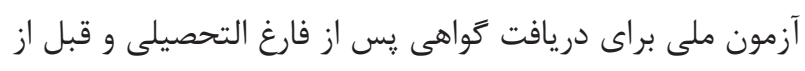


بالينى مربوطه را در محيطى ايمن فرا گرفته و بخش ديخرى

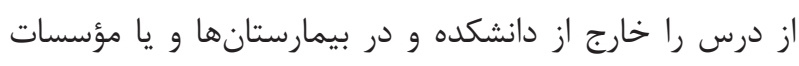

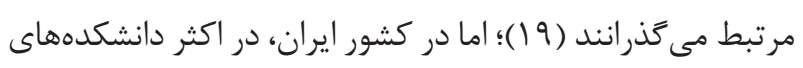

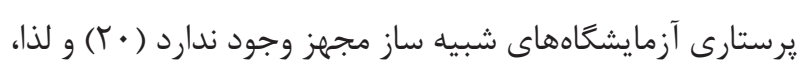

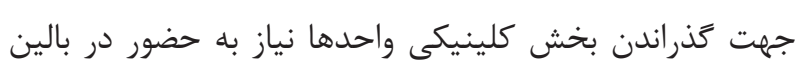

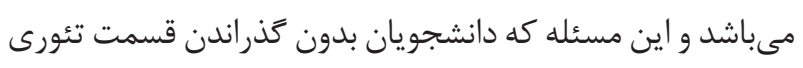

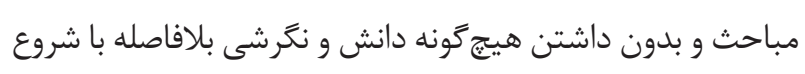

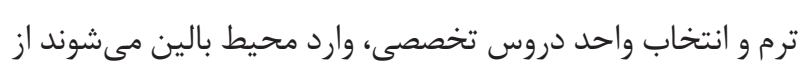

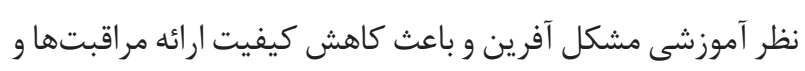

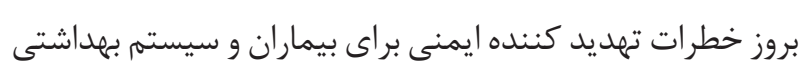
درمانى كردد. مطالعات مختلف نشان مى دهد كه استفاده از شبيه

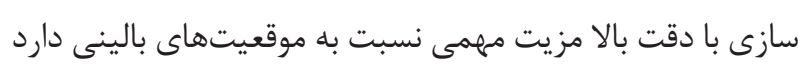

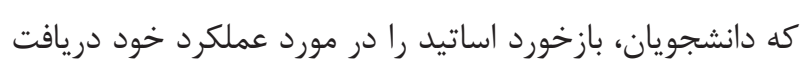

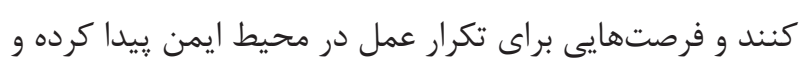

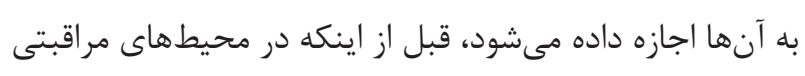

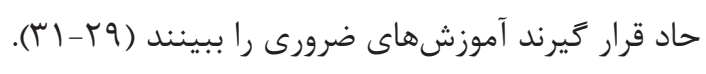

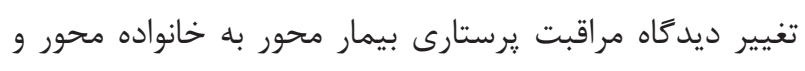

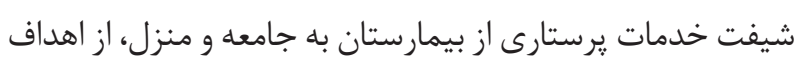

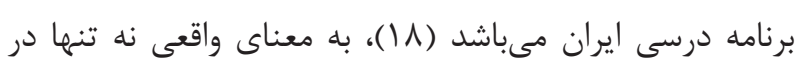

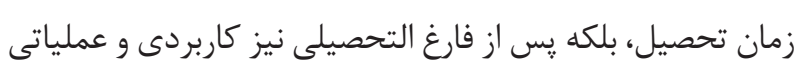

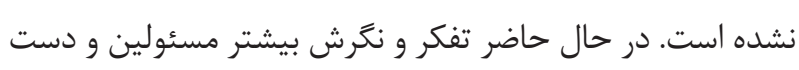
اندر كاران نظام بهداشتى - درمانى ايران، مبتنى بر اشتغال برستاران در سطح دوم ييشخيرى يعنى مراقبتهاى بالينى در بيمارستانها

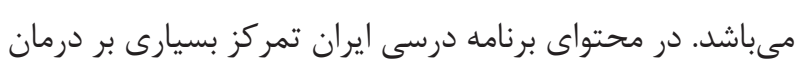

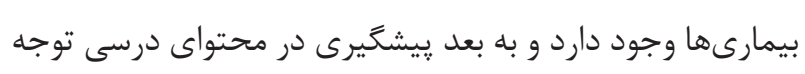

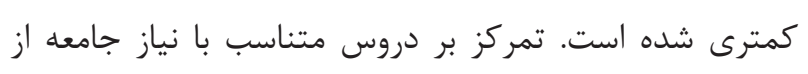

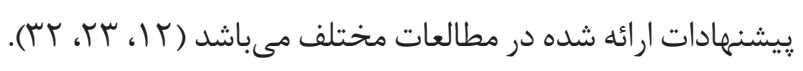

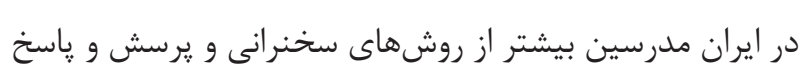

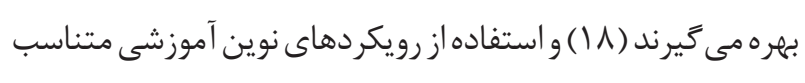

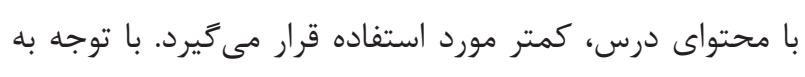

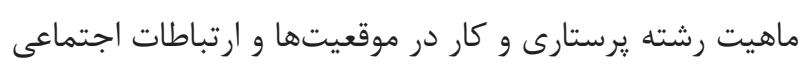
به خصوص با بيماران، اين رشته نيازمند محصلينى است كه از

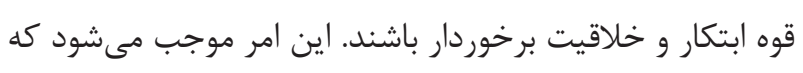

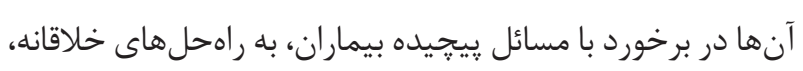

نتايج يك مرور نظام مند در مراقبت مبتنى بر شواهد ايران نشان

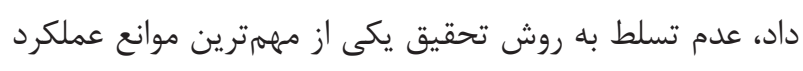

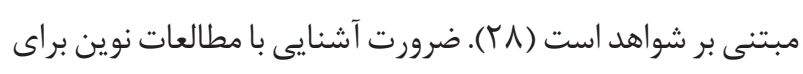

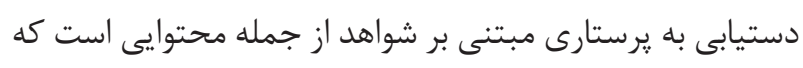

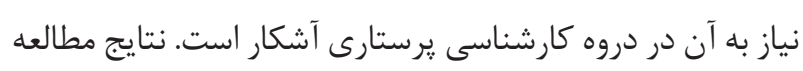

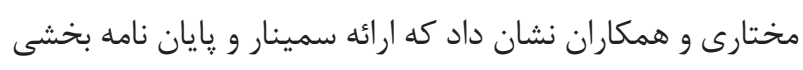

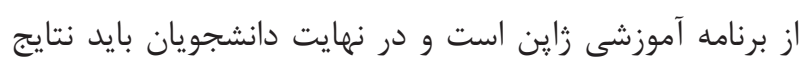

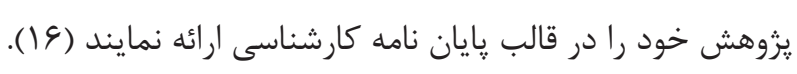

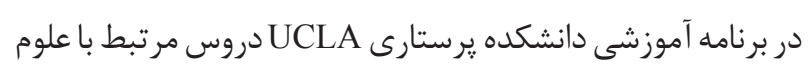

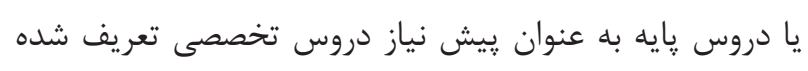

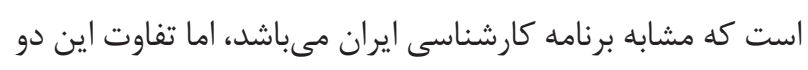

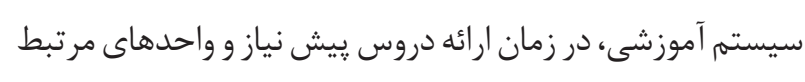

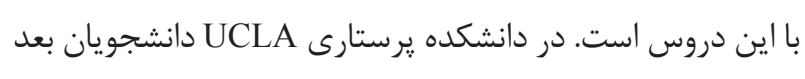

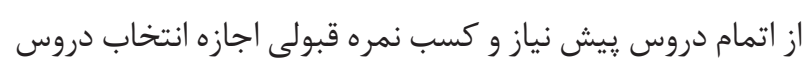

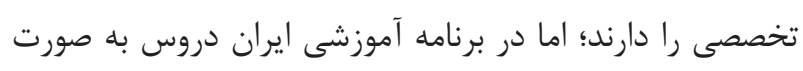

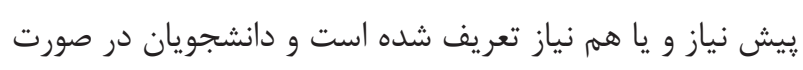

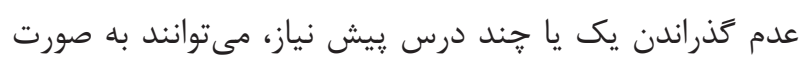

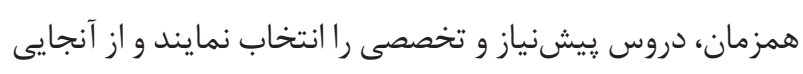

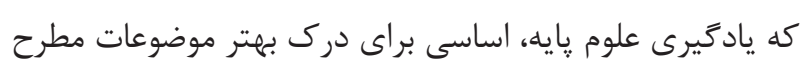

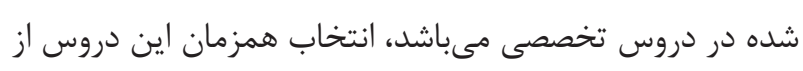
نقاط ضعف برنامه آموزشى كارشناسى يرستارى ايران مى دباشد.

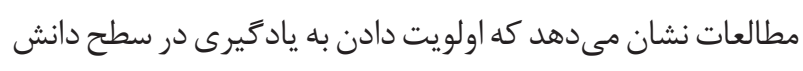

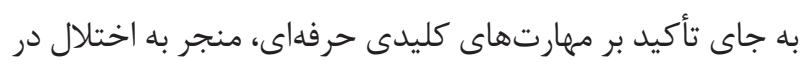

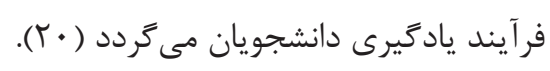

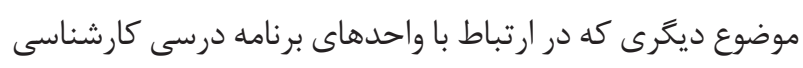

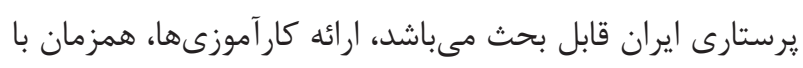
ارائه دروس تخصصى مربوطه در همان نيمسال است كه مشابه ئرئ

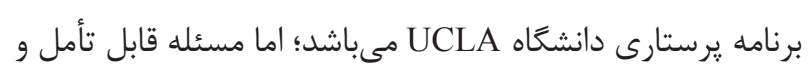
تفاوتى كه بين اين دو برنامه وجود دارد اين است كه در دانشكده ئناه

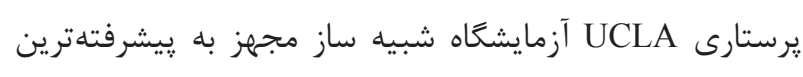
تكنولوزى آموزشى شبيه ساز، شبه بيمار، بيمارستان مجازى و... وجود دارد و بيش از • له درصد واحدهاى كلينيكى در آزمايشگاه

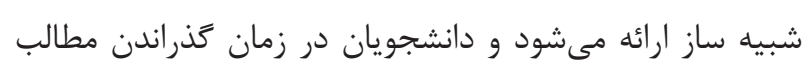
تئورى يك درس، با حضور در آزمايشكاه شبيه ساز موضوعات 
دانشجويان براى ايفاى نقش حرفهاى آنها است. استفاده از

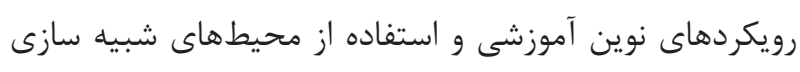
شده مجهز، براى آموزش بعضى دروس بالينى توصيه مى مَىردد.

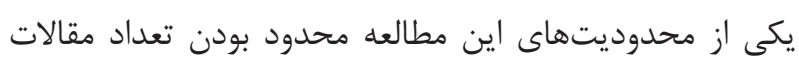

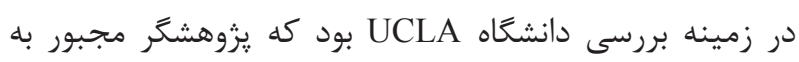
جمع آورى اطلاعات از سايت اين دانشعاه خرديد.

\section{تشكر و قدردانى}

مطالعه حاضر حاصل يروزه درسى واحد نظامهاى آموزشى مقطع ودرانى

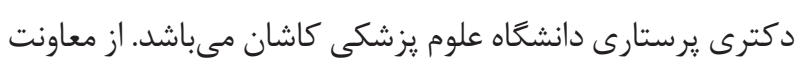

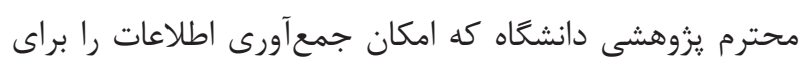
انجام مطالعه فراهم كردند، نهايت تشكر و قدردانى را داريم. دمان.

تضاد منافع هيجكونه تعارض منافعى توسط نويسندًان زَزارش نشده است.

\section{References}

1- Rassouli M, Zagheri Tafreshi M, Mohammadnejad E. Challenges in clinical nursing education in Iran and strategies. Clinical Excellence. 2014;2(1):11-22.

2- Curry DM, Samawi Z. Preparing pediatric nurses for the $21 \mathrm{st}$ century: perceptions of nurse managers, nursing faculty, and staff nurses. J Pediatr Nurs. 2011;26(6):599-603. DOI: 10.1016/j. pedn.2011.09.001 PMID: 22055381

3- Sayf A. Measurement, evaluation and educational Evaluation. Tehran: Doran Publication; 2007.

4- Aliyari S, Maleki H, Pazargadi M, Abbaspour A. Developing and standardization of quality evaluation and accreditation indicators for curricula of baccalaureate degree nursing education in Iran. Annals of Military and Health Sciences Reserch. 2012;10(1):5061.

5- Jaffari F, Valiani M. Evaluation of field training from the viewpoints of management and informatics students of Isfahan university of medical sciences. Iranian Journal of Medical Education. 2002;2(1):19-26.

6- Karimi Moonaghi H, Montazeri R. A comparative study of the curriculum of master's degree in medical education in Iran and some other countries. Strides in Development of Medical Education. 2015;11(4):420-33.
كارساز و مؤثر دست بزنند و از قدرت حل مسئله بالايى برخوردار شوند (Yq). به كار ₹يرى روشهاى آموزش نوين و مبتنى بر تفكر خلاق در اين سيستم از ضروريات آموزشى محسوب مىشود؛ بنابراين مدرسين يرستارى، بايد از روشهاى آموزشى متفاوتى براى آموزش و ياد گيرى بهتر دانشجويان استفاده نمايند. با توجه به افزايش روزافزون دانش يزشكى، ورود علوم و تكنولوزى

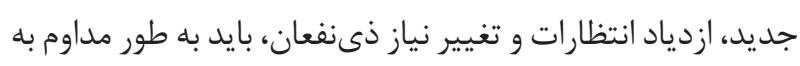
محتوا و تعيين پيامدها در برنامه درسى توجه خاصى نمود. ريشه

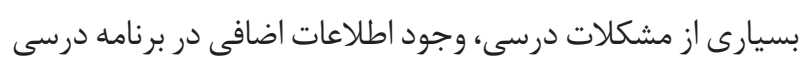
است كه باعث خستخى فراخير و معلم مىشود. در اين راه بايد محتواهاى ضرورى فراهم شود و از يرداختن به محتوايى كه مورد نياز اصلى فراخيران نيست، خوددارى شود. دورههاى كارآموزى و كاروزى در شكلدهى مهارتهاى اساسى و توانمندىهاى حرفهاى دانشجويان يرستارى نقشى اساسى دارد. به طور قطع

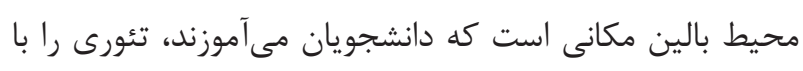
عمل تلفيق نمايند و اين محيط منبع ضرورى در آمادهسازى

children. J Prof Nurs. 2008;24(3):184-91. DOI: 10.1016/j. profnurs.2008.01.001 PMID: 18504034

8- Peimani M, Aalaa M, Pajouhi M. Faculty support for curriculum development in nursing education. FMEJ. 2011;4(3):45-50.

9- Ramezani T, Dortaj RA. Characteristics of Effective Teachers and Pertinent Efective Educational Factors According to the Teachers and Students'point of View in Schools of Nursing, Kerman University of Medical Sciences. Strides Dev Med Educs. 2009;6(2):139-48.

10- Hall CE. Toward a model of curriculum analysis and evaluation - Beka: a case study from Australia. Nurse Educ Today. 2014;34(3):343-8. DOI: 10.1016/j.nedt.2013.04.007 PMID: 23683812

11- Makarem A, Movahed T, Sarabadani J, Shakeri M, Asadian Lalimi T, Eslami N. Evaluation of educational status of oral health and community dentistry department at Mashhad Dental School using CIPP evaluation model in 2013. Journal of Mashhad Dental School. 2014;38(4):347-62.

12- Sadat-Aghahosseini S, Navab E, Sadooghiasl A. A comparative study on curriculum of geriatric nursing master's degree in Iran and Ireland. Nursing Practice Today. 2016;3(1):19-25.

13- Kermanshahi s, Memarian R, Hseni A, Zmzam S, Nzamli F. A comparison post-graduate MS curriculum of nursing education in Iran and Canada. J Med Educat Development. 2011;4(6):48-54. 
14- Nikfarid L, Ashktorab T. Understanding of neonatal intensive care nurse practitioner students of situation of their profession in Iran: A qualitative study. IJNR. 2013;8(29):37-46.

15- Ghorbani F, Rahkar Farshi M. Comparison of Master's curriculum of pediatric nursing in Iran and United states. J Nursing Education (Jne). 2015;4(3):41-7.

16- Mokhtari Nouri J, Nezamzadeh M. Comparative study of nursing education in Iran and Japan. Clinical Excellence. 2016;4(2):81-99.

17- Aghazadeh A. The Principles and Rules Governing the Process of Citizenship: Investigating the Characteristics and Changes Happened in Citizenship Education in Japan. J Edu Inno. 2006;5(17):66-45.

18- Mo. H. phd in Nursing Created by Supreme Council of Planning University of Medical Sciences. Available from: http:// mbsbehdashtgovir/uploads/MsParast.

19- Davis. CT. Academics -Ph.D. program Created by: Betty Irene Moore School of Nursing at UC Davis Available from: http:// wwwucdmcucdavisedu/nursing/academics/programs/phdhtml.

20- Nouhi E, Ghorbani-Gharani L, Abbaszadeh A. A Comparative Study of the Curriculum of Undergraduate Nursing Education in Iran and Selected Renowned Universities in the World. sdmej. 2015;12(3),

21- Farsi Z, Dehghan-Nayeri N, Negarandeh R, Broomand S. Nursing profession in Iran: an overview of opportunities and challenges. Jpn J Nurs Sci. 2010;7(1):9-18. DOI: 10.1111/j.17427924.2010.00137.x PMID: 20618672

22- Tabari Khomeiran R, Deans C. Nursing education in Iran: past, present, and future. Nurse Educ Today. 2007;27(7):708-14. DOI: 10.1016/j.nedt.2006.10.003 PMID: 17125890

23- Arian M, Nobahar M, Babamohamadi H. Comparative Study of
Nursing Master's Education Program in Iran and John Hopkins School of Nursing. Journal of Nursing Education. 2018;7(3):3448.

24- Goodare P. Literature review. Australian Journal of Advanced Nursing, The. 2015;33(1):38.

25- Manzari M.AStudy of Teachers'Attitudinal Changes in Elementary School toward Educational Responsibilities in 2014-2015 from the Viewpoints of Instructors in Farhangian University. Educational Development of Judishapur. 2016;7(Supplement):36-41.

26- Amini K, Ghahremani Z, Moosaeifard M, Tagiloo G. Comparison of Nursing Education System in Iran and China. J Med Educat Develop. 2016;9(21):109-18.

27- Adib-Hajbaghery M. Factors influencing evidence-based nursing: A qualitative study. Iran J Nursing. 2006;19(47):17-33.

28- Ghojazadeh M, Azami AS, Naghavi BM. Evidence-based care in Iran: a systematic review. J Birjand Univ Med Sci. 2014;21(2):14259.

29- McCallum J, Ness V, Price T. Exploring nursing students' decision-making skills whilst in a Second Life clinical simulation laboratory. Nurse Educ Today. 2011;31(7):699-704. DOI: 10.1016/j.nedt.2010.03.010 PMID: 20807671

30- Duff E, Miller L, Bruce J. Online Virtual Simulation and Diagnostic Reasoning: A Scoping Review. Clinical Simulation in Nursing. 2016;12(9):377-84. DOI: 10.1016/j.ecns.2016.04.001

31- Verkuyl M, Mastrilli P. Virtual simulations in nursing education: A scoping review. J Nurs \& Health Sci. 2017;3(2):39-47.

32- Sajadi SA, Rajai N, Mokhtari Nouri J. Comparison of the Curricula of Master of Science in Nursing (MScN) Programs in Iran and Japan: A Descriptive Comparative Study. sdmej. 2017;14(2). DOI: $10.5812 /$ sdme. 64082 . 